\title{
Eriobotrya Japonica Lindl. Kernels: Assessment of Polysaccharides and Kinetics of Thermal Degradation under Inert Atmosphere Using Coats-Redfern Method
}

\author{
Maryam El Marouani ${ }^{1}$, Sarah Bentahar ${ }^{2}$, Lahcen El Hamdaoui ${ }^{3 *{ }^{\circledR}}{ }^{\text {, László Trif }}{ }^{4}$, Rachida Zerrouki ${ }^{5}$, \\ Guy Costa ${ }^{5}$, Fatima Kifani-Sahban ${ }^{2}$
}

1 Department of Chemistry, College of Sciences, University of Hafr Al Batin, Hafr Al Batin, Kingdom of Saudi Arabia

2 Team of Modeling and Simulation of Mechanical and Energetic, Physical Department, Faculty of Sciences, Mohammed V University, Rabat, Morocco

3 Laboratory of Materials, Nanotechnology, and Environment, Center of Material Sciences, Department of Chemistry, Faculty of Sciences, Mohammed V University, Rabat, Morocco

4 Institute of Materials and Environmental Chemistry, Research Centre for Natural Sciences, 1117 Budapest, Magyar tudósok körútja 2, Hungary

5 Laboratoire Peirene, Equipe Sylva LIM (EA 7500), Faculté des Sciences et Techniques, 87060 Limoges Cedex, France

* Correspondence: la.elhamdaoui@gmail.com;

Scopus Author ID 57190738516

Received: 18.07.2020; Revised: 24.08.2020; Accepted: 26.08.2020; Published: 30.08.2020

\begin{abstract}
This work aims to extrapolate the energy conversion of Raw Loquat Kernels (RLK) by pyrolysis under the inert atmosphere. For this purpose, the main physicochemical composition of the RLK was first investigated. The proximate analysis shows that RLK has a relatively low moisture content, an absence of heavy metals, and the presence of an important amount of organic matter. In order to evaluate polysaccharides composition, RLK was dissolved in 1-ethyl-3-methylimidazolium bromide [Emim] $\mathrm{Br}$ ionic liquid; the resulting solutions are then immuno-labeled with monoclonal Antibodies (mAbs) against plant cell wall polysaccharides epitopes. Polysaccharides have been then analyzed using the ELISA technique with a set of $14 \mathrm{mAbs}$ against hemicellulose and pectin. The LM19 immuno-labeling was more intense after 3 days of treatment at $80{ }^{\circ} \mathrm{C}$, followed by 2 hours at $100{ }^{\circ} \mathrm{C}$, indicating the important amount of un-esterified Homogalacturonans among RLK polysaccharides. Xray diffraction pattern indicates the presence of a small amount of crystalline cellulose. Surface functional groups and morphology of RLK were also investigated. RLK was then subjected to thermal analyses TG/DTG, DTA, and DSC under an inert atmosphere. The kinetic parameters were determined by the Coats-Redfern method. The highest activation energies were found in the first thermal degradation region where the main pyrolysis reaction took place, and the largest weight loss occurred, with energy values running from 24.34 to $117.06 \mathrm{KJ} / \mathrm{mol}$.
\end{abstract}

Keywords: Raw Loquat Kernels (RLK); antibodies (mAbs); Kinetics; TGA; Coats-Redfern.

List of symbols: TGA: Thermogravimetric analysis; DTG: Derivative thermogravimetry; $f(\alpha)$ : Represents the mode of degradation of the substance; $g(\alpha)$ : Integral form of the function $f(\alpha)$; A: Preexponential factor $\left[\mathrm{min}^{-1}\right]$; E: Apparent activation energy $\left[\mathrm{KJ} . \mathrm{mol}^{-1}\right]$; $\mathrm{k}$ : Reaction rate constant $\left[\mathrm{min}^{-1}\right] ; \mathrm{m}_{0}:$ Initial weight of the sample $[\mathrm{mg}] ; \mathrm{m}_{\mathrm{t}}$ : Weight of the sample at the particular temperature $\mathrm{T}[\mathrm{mg}] ; \mathrm{m}_{\infty}$ : Weight at the end of degradation step $[\mathrm{mg}] ; \quad \beta$ : Heating rate $\left[{ }^{\circ} \mathrm{C} \cdot \mathrm{min}^{-1}\right]$; R: Constante des gaz parfait $\left[\mathrm{J} \cdot \mathrm{mol}^{-1} \cdot \mathrm{K}^{-1}\right] ; \mathrm{T}$ : Absolute temperature $[\mathrm{K}] ; \mathrm{T}_{0}$ : Initial temperature [K]; t: Time [min]; $\mathrm{n}$ : Reaction order; $\alpha$ : Conversion rate.

(C) 2020 by the authors. This article is an open-access article distributed under the terms and conditions of the Creative Commons Attribution (CC BY) license (https://creativecommons.org/licenses/by/4.0/). 


\section{Introduction}

Loquat (Eriobotrya japonica Lindl.) is a subtropical evergreen fruit tree native to the southeast of China, belonging to the Maloideae subfamily of the Rosaceae. Loquat is cultivated in Cyprus, Egypt, Greece, Israel, Italy, Spain, Tunisia, and Turkey. It is also widely distributed in many European, Asian, and American countries [1,2]. Loquat was introduced and cultivated to Zegzel valley (region of Berkan, Marrakech, Fes-Meknes, Khemisset, and Tetouan), in Morocco in the sixties [3]. Indeed, under the Morocco Green Plan launched in recent years (PMV), loquat trees have benefited from subsidies for rehabilitation and the densification of existing plantations and the creation of new modern ones [4]. This plan has led to an increase in the production of loquat fruit. Thus, according to the latest data [4], its total area is 270 ha and production of $7200 \mathrm{t}$ with an average return of 20-25 t/ha. Together with the increase in loquat fruit production, the amount of waste associated with the packaging and production of pulp and loquat juice, especially loquat kernels, significantly increased too [4]. Although the loquats are small fruits of 3 to $5 \mathrm{~cm}$ in diameter, in the form of a spinning top, their flesh surrounds maximally four kernels, which represents almost $90 \%$ of the total weight of the fruit.

Based on the above consideration, loquat kernels are accordingly of significant economic interest, that is why their valuation is important. Knowledge of raw kernels composition is therefore essential for any further application. Thus, loquat kernels contain extractable components with high added value. They are rich in protein, dietary fiber, phenolic compounds, and antioxidants [5].

Loquat kernels contain active components highly used in various fields, including medicine and cosmetics. One can find them in the manufacturing of activated carbon [6] and as bio-adsorbents for dyes removal [7, 8]. They are also substrates for bacterial [9] and methane fermentation [10]. Loquat kernels also contain a large number of cyanide compounds, such as amygdalin, known for its anti-tumor efficacy. Indeed, in Asian countries, the powder of the loquat kernels was consumed for medicinal purposes, especially against cancer. It has been found that during its digestion, the cyanides contained in kernels turn into hydrocyanic acid toxic when decomposed in the human body. This is why the food and drug authorities have denied their use in traditional medicine. Regarding the amygdalin extracted from loquat seeds, it is prescribed under medical supervision, yet, the effective therapeutic doses being established for the moment only in vivo [11]. However, loquat kernels are used in the food industries giving the fact that they contain a high amount of starch [12].

However, despite the fact that loquat kernels have been the subject of several studies in recent years, as well as the fact that the presence of bioactive compounds in its composition has been proven, no detailed polysaccharides investigation has been carried out on loquat kernels thermal decomposition to our knowledge. In addition, no reviews on loquat kernels kinetic data were found, and their energy features and valuation as fuel are still not sufficiently discussed. Therefore, we propose in this work to examine the thermal profile of loquat kernels in order to highlight their energy potential and the possibility to use them as fuel.

The most emphasis related to the use of biomass fuels, for environmental or economic reasons, demands a larger knowledge of kinetic parameters involved in the thermo-conversion reactions. The kinetic investigation is one of the most important applications of thermal analysis, once the knowledge of the kinetic parameters, mechanisms, and mathematical models associated to the thermal decomposition process, can take to the improvement of the current 
practices of biomass conversion, modeling of industrial processes and combustion in furnaces and boilers.

Degradation kinetics can be studied by several methods, but one of the most popular and simplest techniques widely used in the literature is the thermogravimetric analysis [13]. Literature reviews present several kinetic models related to the pyrolysis of biomass fuels, e.g., the single reaction model, the consecutive reaction model, and the independent parallel model (IPR) [14].

In this work, the characteristics of mass loss are discussed, and kinetic parameters associated with thermal volatilization of RLK are determined. To reach the kinetic parameters from the thermogravimetric data, we opted for the Coats Redfern method, given its precision in the determination of the degradation mechanisms for one single heating rate.

\section{Materials and Methods}

\subsection{Material.}

Fresh loquat (Eriobotrya japonica Lindl.) fruits were purchased from a local market in Berkane. Firstly, the seeds were manually removed from the flesh (edible parts) and other tissues. The seed testa or seed skin was separated from the kernel, and the loquat kernel was recovered. Kernels were cleaned once with distilled water to remove the undesirable materials, dried in the oven at $60^{\circ} \mathrm{C}$ for $24 \mathrm{~h}$. The seeds are then crushed using a micro-grinder and sieved, and the particle size used in this work is less than/or equal to $180 \mu \mathrm{m}$.

The 1-ethyl-3-methylimidazolium bromide [Emim] $\mathrm{Br}$ ionic liquid and diethyl ether were purchased from Aldrich and used without further purification.

\subsection{Methods of material analyses.}

\subsubsection{Proximate analysis.}

Proximate analysis of raw loquat kernels was performed according to AOAC (1995, 1997 and 2000) [15-17]. Thus, the moisture content was measured gravimetrically by drying the sample in an air oven at $100{ }^{\circ} \mathrm{C}$ until it reached a constant weight. Total nitrogen was determined by the Kjeldahl method (AOAC, 1997) [16], followed by the protein calculation using the general factor 6.25. Fat content was quantified by the Soxhlet method using ether as a solvent for 6 hours at $70^{\circ} \mathrm{C}$ and then removing the solvent by distillation. Ash was determined by combusting dry samples in a muffle furnace (Thermolyne 62700 ) at $525{ }^{\circ} \mathrm{C}$ for around 18 h. All values are expressed as mean $(n=3)$. Dry matter $(D M)$, organic matter $(\mathrm{OM})$, and total carbohydrates content are estimated using the following equations:

$$
\begin{gathered}
\mathrm{DM}=100 \text { - fat - Moisture } \\
\mathrm{OM}=100 \text { - Ashes }
\end{gathered}
$$

Total carbohydrates content $=100-[\%$ moisture $+\%$ protein $+\%$ fat $+\%$ Ash $]$ (Weende method $)$

$\%$ lignin $=\mathrm{OM}$ - total carbohydrates content (Weende method)

The energy value is evaluated using the formula described by Egan et al. [18]

$$
\text { Energy }=(\% \text { fat } \times 37 \mathrm{~kJ} / \mathrm{g})+(\% \text { protein } \times 17 \mathrm{~kJ} / \mathrm{g})+(\% \text { carbohydrate } \mathrm{x} 16 \mathrm{~kJ} / \mathrm{g})
$$




\subsubsection{Ultimate analyses and higher heating values HHV.}

The total elemental content of $\mathrm{C}, \mathrm{H}, \mathrm{N}$, and $\mathrm{S}$ in samples was measured on a CHNS analyzer (series II, PerkinElmer, USA). The percentage of oxygen content was then calculated using the following equation:

$$
\mathrm{O}(\%)=100-(\mathrm{C}+\mathrm{H}+\mathrm{N}+\mathrm{S}+\% \text { ash })
$$

The higher heating value (HHV) of the investigated sample was estimated using the ultimate analysis data; C, H, O and $\mathrm{N}$ contents; using the formula described by Ayhan Demirbas [19]

$$
\mathrm{HHV}=\{33.5[\% \mathrm{C}]+142.3[\% \mathrm{H}]-15.4[\% \mathrm{O}]-14.5[\% \mathrm{~N}]\} \times 10-2(\mathrm{MJ} / \mathrm{kg})
$$

\subsubsection{Polysaccharides immunodetection.}

Samples were solubilized in ionic liquid 1-ethyl-3-methylimidazolium bromide [Emim] Br after 5 minutes of activation in the microwave at a maximum temperature below 80 ${ }^{\circ} \mathrm{C}$ and a power of $200 \mathrm{~W}$. The solubilized polysaccharides are quantified via an antigenantibody reaction through an Enzyme-linked immunosorbent assay (ELISA) for the rapid detection of polysaccharides, with a set of 14 monoclonal antibodies (mAbs) as described (Table 1). The revelation was done in $50 \mu \mathrm{L}$ of 1-Step Ultra TMB (3.3',5,5'Tetramethylbenzidine) - ELISA Substrate Solution (Life Technologies) for 20 min before being stopped by adding $50 \mu \mathrm{L}$ of $0.5 \mathrm{~N}$ sulfuric acids. Absorbance has been read at $450 \mathrm{~nm}$ and $655 \mathrm{~nm}$ with a microplate reader (BMG-Labtech, FLUOstar Omega) [20].

Table 1. Monoclonal list of antibodies (mAbs)

\begin{tabular}{l|l} 
Antibody & Polymers recognition \\
\hline LM21 & Mannan, glucomannan, galactomannan \\
\hline LM10 & Un-substituted xylan, low substituted arabinoxylan \\
\hline LM25 & Xyloglucan, XLLG, XXLG, XXXG \\
\hline LM5 & Galactan \\
\hline LM19 & Un-esterified Homogalacturonan \\
LM6 & Arabinan \\
Antibody: name code of the antibody, \\
Polymer recognition: epitope or polysaccharide recognized by the antibody.
\end{tabular}

\subsubsection{X-ray diffraction.}

The X-ray powder diffraction diagram of raw loquat kernels is recorded with a diffractometer Siemens D5000 type using K $\alpha_{1}$ ray of copper $(\lambda=1.5406 \AA)$.

The degree of relative crystallinity was quantitatively estimated, following the method described in the literature [21]. A smooth curve, with connecting peak baselines, was computed and plotted on the diffractograms. The area above the smooth curve was taken as the crystalline portion, and the lower area between the smooth curve and the linear baseline, which covers the $2 \theta$ range from 5 to 50 , was taken as the amorphous section. The upper diffraction peak area and the total diffraction area over the diffraction angle 5-50 were integrated. The ratio of upper area to total diffraction was used as the degree of relative crystallinity. The equation for calculating the degree of relative crystallinity is as follows:

$$
X_{c}=\frac{A_{p}}{A_{b}}+A_{b}
$$

Where $X_{c}$ refers to the degree of relative crystallinity, $A_{p}$ refers to the crystallized area on the $\mathrm{X}$-ray diffractogram, and $\mathrm{A}_{b}$ refers to the amorphous area on the X-ray diffractogram [21]. 


\subsubsection{Infrared characterization.}

The apparatus used for the characterization by infrared spectroscopy is a Bruker-Tensor 27 , which operates in reflection mode. This apparatus is equipped with a Globar source that emits radiation in the region of mid-infrared and of a DLaTGS detector. In the unity of Attenuated Total Reflection (ATR), enough of the sample is placed, without prior preparation, on the diamond crystal, which allows the acquisition between 4000 and $500 \mathrm{~cm}^{-1}$. The number of scans is 20 , with a resolution of $4 \mathrm{~cm}^{-1}$. The device is controlled by OPUS software.

\subsubsection{Scanning electron microscopy (SEM) analyses.}

The surface morphology observation of loquat kernels was made on an S-4800 equipment (Hitachi, Tokyo, Japan). The samples were analyzed at an accelerating voltage of $13.6 \mathrm{kV}$.

\subsubsection{Thermogravimetric and differential thermal analyses.}

The thermogravimetric (TG) and differential thermal analyzes (DTA) of loquat kernels were made on a simultaneous thermal analyzer of the 'LabsysTMEvo (1F)' type and SETARAM brand. This device consists of a TG microbalance associated with a DTA sensor with a single rod, a metal resistor furnace up to $1600{ }^{\circ} \mathrm{C}$, and multitasking software controlling the various modules. The tests are carried out from ambient temperature to $600{ }^{\circ} \mathrm{C}$ with a temperature rise rate of $20^{\circ} \mathrm{C} / \mathrm{min}$ under argon with a flow rate of $10 \mathrm{~cm}^{3} / \mathrm{min}$. The initial mass of samples is about $10 \mathrm{mg}$, and the particle size is of $180 \mu \mathrm{m}$. Three replicates were used for thermogravimetric and differential thermal analyzes.

\subsubsection{Differential scanning calorimetry.}

The differential scanning calorimetry (DSC) measurements are carried out on a SETARAM DSC 12 type apparatus. The tests are carried out from ambient temperature to 500 ${ }^{\circ} \mathrm{C}$, under argon with a flow rate of $10 \mathrm{~cm}^{3}$ and a temperature rise rate of $5{ }^{\circ} \mathrm{C}$. $\mathrm{min}^{-1}$. The initial mass of the sample is about $10 \mathrm{mg}$, and the particle size of the order of $180 \mu \mathrm{m}$.

\subsubsection{Kinetic approach.}

Coats-Redfern method [13, 22, 23], which is given in Eq.2, is used for the determination of kinetic parameters of RLK.

$$
\operatorname{Ln}\left(\frac{g(\alpha)}{T^{2}}\right)=\operatorname{Ln} \frac{A R}{\beta E_{\alpha}}-\frac{E_{\alpha}}{R T}
$$

where $\alpha$ is a characteristic variable of reaction progress of the sample, and $\mathrm{T}$ is the absolute temperature, $\mathrm{g}(\alpha)$ represents functions commonly used for the description of thermal decomposition (Table 2). $\mathrm{A}$ is the frequency factor, $\mathrm{E}_{\mathrm{a}}$ is the activation energy, $\mathrm{R}$ is the gas constant, and $\beta$ is the heating rate.

A plot of $\operatorname{Ln}\left(g(\alpha) / T^{2}\right)$ against $1 / T$ will give a straight line of slope $-E_{a} / R$ and an intercept of $\ln (\mathrm{AR} / \beta \mathrm{E})$ for an appropriate form of $\mathrm{g}(\alpha)$. Thus, based on the correct form of $g(\alpha), \mathrm{E}_{\mathrm{a}}$ and A could be respectively determined from the slope and intercept terms of the regression line. Table 1 lists the most common kinetic $\mathrm{g}(\alpha)$ functions, which were used in this work for the evaluation of reaction mechanisms from TG curves by using the Coats-Redfern method. 
Table 2. Kinetic parameter functions.

\begin{tabular}{|c|c|c|}
\hline Degradation mode & Code & $g(\alpha)=\int_{0}^{\alpha} \frac{d \alpha}{f(\alpha)}$ \\
\hline \multicolumn{3}{|l|}{ Diffusion } \\
\hline One-way transport & D1 & $\alpha^{2}$ \\
\hline two-way transport, Valensi-Barrer [24] & $\mathrm{D} 2$ & $\alpha+(1-\alpha) \operatorname{Ln}(1-\alpha)$ \\
\hline three-way transport, Jander [25] & D3 & {$\left[1-(1-\alpha)^{1 / 3}\right]^{2}$} \\
\hline Ginstling-Brounshtein [26] & D4 & $1-2 \alpha / 3-(1-\alpha)^{2 / 3}$ \\
\hline Zhuravlev & D5 & {$\left[1 /(1-\alpha)^{1 / 3}-1\right]^{2}$} \\
\hline Anti-Jander & D6 & {$\left[(1+\alpha)^{1 / 3}-1\right]^{2}$} \\
\hline Kroger-Ziegler & D7 & $\left.\left[1-(1-\alpha)^{1 / 3}\right)\right]^{2}-\log (t)$ \\
\hline Two dimensions, Jander & D8 & $\left.\left[1-(1-\alpha)^{1 / 2}\right)\right]^{2}$ \\
\hline Two dimensions, Anti-Jander & D9 & {$\left[(1+\alpha)^{1 / 2}-1\right]^{2}$} \\
\hline Interfacial transfer & D10 & {$\left[1 /(1-\alpha)^{1 / 3}-1\right]$} \\
\hline Transfer and diffusion & D11 & $\begin{array}{l}1 /(1-\alpha)^{1 / 3} \\
1+1 / 3 \operatorname{Ln}(1-\alpha)\end{array}$ \\
\hline Diffusion with two directions & D12 & $\begin{array}{l}1 / 5(1-\alpha)^{-5 / 3}-1 / 4(1- \\
\alpha)^{-4 / 3}+1 / 20\end{array}$ \\
\hline \multicolumn{3}{|l|}{ Random nucleation and nuclei growth } \\
\hline $\begin{array}{l}\text { Avrami-Erofeev }[27,28] \\
\mathrm{n}=1,2,3,4 \text { et } 5\end{array}$ & An & $\begin{array}{l}{[-\operatorname{Ln}(1-\alpha)]^{z}} \\
\mathrm{z}=1 / 4,1 / 2,1 / 3,3 / 4 \\
\text { and } 2 / 3\end{array}$ \\
\hline \multicolumn{3}{|l|}{ Chemical reactions } \\
\hline Zero-order & F0 & $\alpha$ \\
\hline First-order & F1 & $-\operatorname{Ln}(1-\alpha)$ \\
\hline Second-order & F2 & $(1-\alpha)^{-1}-1$ \\
\hline $\begin{array}{l}\text { Contraction (surface, volume and interface } \\
\text { respectively for } n=2,3 \text { and } 4)\end{array}$ & $\mathbf{R n}$ & $\begin{array}{l}1-(1-\alpha)^{z} \\
z=1 / 2,1 / 3 \text { and } 2 / 3\end{array}$ \\
\hline \multicolumn{3}{|l|}{ Power / Exponential } \\
\hline $\begin{array}{l}\text { Low power (half, third and quarter respectively for } n \\
=2,3 \text { and } 4 \text { ) }\end{array}$ & Pn & $\begin{array}{l}\alpha^{y} \\
y=1 / 2,1 / 3 \text { et } 1 / 4\end{array}$ \\
\hline Exponential & E1 & $\operatorname{Ln}(\alpha)$ \\
\hline
\end{tabular}

For both studied samples, all of the mechanisms in Table 2 were tested, and calculation results were compared. The main purpose was to select the mechanism of the thermal degradation of RLK.

\section{Results and Discussion}

\subsection{Proximate, ultimate analyses, and higher heating values $H H V$ of $R L K$.}

The proximate analysis of raw loquat kernels and energy value expressed in $(\mathrm{Kcal} / 100 \mathrm{~g})$ are gathered in table 3 .

Table 3. Proximate analysis of raw loquat kernels (\%) and energy value (Kcal/100g).

\begin{tabular}{l|l} 
Moisture & 9.73 \\
Ash & 1.60 \\
Crude fat & 4.10 \\
Crude protein & 7.92 \\
DM & $\mathbf{8 7 . 1 7}$ \\
OM & 97.1 \\
total carbohydrates & $\mathbf{7 1 . 4 3}$ \\
Lignin & 13.32 \\
Energy & $\mathbf{3 4 1 . 5 3}$
\end{tabular}

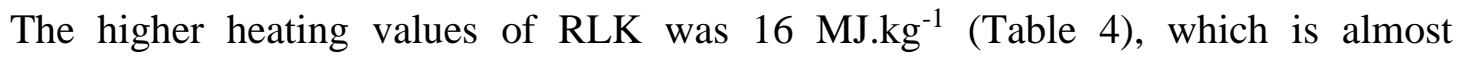
comparable to the energy content of multiple agricultural byproducts such as rapeseed straw (17.64 MJ.kg ${ }^{-1}$ ) [29], pine chips (18.98 MJ.kg-1) [30], and Hardwood (19.10 MJ.kg-1) [31, 32]. 
Softwood [33] presents higher heating values compared to other biomass types. For the same

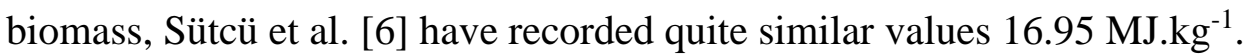

Table. 4. Ultimate composition (wt\% dry basis) and HHV (kcal/kg) (dry basis) of RLK.

\begin{tabular}{|c|c|c|c|c|c|c|}
\hline \multirow{2}{*}{ Sample } & \multicolumn{5}{|c|}{ Ultimate analysis (wt\% dry basis) } & \multirow{2}{*}{$\begin{array}{l}\text { HHV (MJ /Kg) } \\
\text { (dry basis) }\end{array}$} \\
\hline & $\% \mathrm{C}$ & $\% \mathrm{H}$ & $\% \mathrm{~N}$ & $\% \mathrm{O}$ & $\% \mathrm{~S}$ & \\
\hline $\begin{array}{l}\text { RLK } \\
\text { present study }\end{array}$ & 43.60 & 6.27 & 0.46 & 47.95 & 0.12 & 16 \\
\hline RLK [6] & 42.38 & 6.60 & 0.58 & 47.82 & 0.084 & 16.95 \\
\hline Hardwood [32] & 48.2 & 5.6 & 0.9 & 45.3 & - & 17 \\
\hline Softwood [33] & 47 & 7.7 & 0.1 & 45.2 & - & 24 \\
\hline
\end{tabular}

3.2. Polysaccharide immuno-detection.

In [Emim]Br, only 3 days in IL at $80{ }^{\circ} \mathrm{C}$ were enough to completely dissolve RLK powder ground into liquid nitrogen in a Retsch ball-mill.

This can be explained by a greater fineness of the ground powder in liquid nitrogen. After dissolution at $80^{\circ} \mathrm{C}$ or at $80{ }^{\circ} \mathrm{C}$ followed or not by $2 \mathrm{~h}$ at $100^{\circ} \mathrm{C}$, soluble polysaccharides could be well-identified whatever the treatment and the type of the antibodies used. The standard deviation of repeated measurements is rather low (Figure 1), even if some standard deviations are higher for some samples. The method stays reproducible for all the antibodies. Regarding the results for the RLK (Figure 1), immuno-labeling is comparable regardless of the dissolution treatment for LM25, LM19, LM6, and LM21 antibodies. The LM19 immunolabeling is more intense after the 3-day treatment at $80^{\circ} \mathrm{C}$ RLK than the other treatments. However, the labeling differences between treatments are low, which allows us to suggest that time and temperature have a slight impact on RLK dissolution and polysaccharide immunodetection.

Important amounts of un-esterified Homogalacturonans and xyloglucans are detected, with traces of Mannanes and Galactanes and complete absence of Arabinanes and Xylanes among loquat seeds polysaccharides.

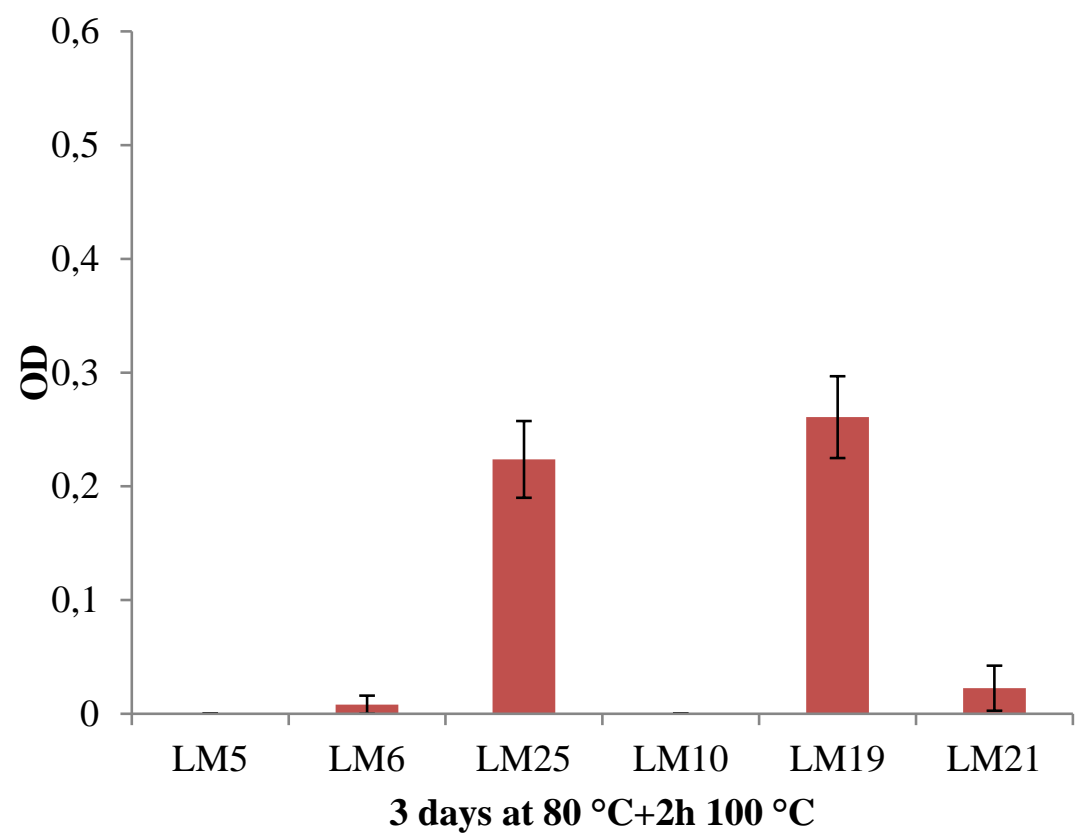

Figure 1. Immuno-labeling intensity (OD) measurement for a set of 6 antibodies in the function of time and temperature after RLK polysaccharide dissolution in [Emim]Br. 
Quantities of RLK dissolved: $10 \mu \mathrm{g}$ for CCRC-M14, LM19, LM25, 5 $\mu \mathrm{g}$ for LM5, and $0.5 \mu \mathrm{g}$ for LM11 and LM21. Dissolution and ELISA were done in triplicate.

\subsection{X-ray diffraction pattern.}

X-ray diffraction patterns of raw loquat kernels are given in Fig. 2. The diffractogram does not exhibit a basic horizontal line. This shows that the major part of the matter is amorphous. However, a few diffraction peaks emerge from the basic line, indicating the presence of a small amount of crystalline matter.

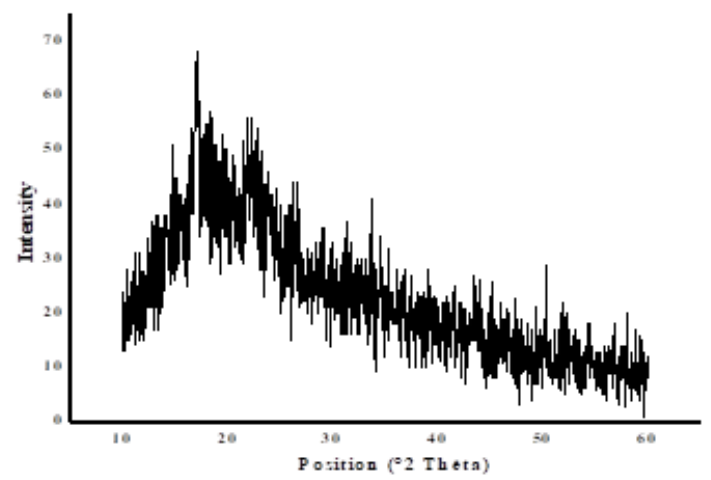

Figure 2. X-ray diffraction patterns of loquat kernels.

The XRD pattern of RLK has been compared to those of native cellulose $\left(\mathrm{C}_{6} \mathrm{H}_{12} \mathrm{O}_{6}\right)$, xylane dehydrate $\left(\mathrm{C}_{10} \mathrm{H}_{12} \mathrm{O}_{9.2} \mathrm{H}_{2} \mathrm{O}\right)$, or hemicellulose dehydrates given in the JCPDF crystallographic database (Table 5).

Table 5. Bragg diffraction angle $\left({ }^{\circ} 2 \mathrm{Th}\right)$ and reticular distance $(\mathrm{d})$ of RLK and their corresponding compounds identified in the JCPDF crystallographic database.

\begin{tabular}{l|l|l} 
Pos. $\left[{ }^{\circ} \mathbf{2} \theta\right]$ & $\mathbf{d}(\AA)$ & Corresponding compounds \\
\hline $\mathbf{1 8 . 4 9 2 1}$ & 5.57122 & N.Cel et HCel \\
\hline $\mathbf{2 2 . 9 8 8 7}$ & 4.49214 & N.Cel et HCel \\
\hline $\mathbf{2 7 . 4 2 0 9}$ & 3.77678 & C \\
\hline $\mathbf{3 0 . 8 2 4 6}$ & 3.36824 & HCel \\
\hline $\mathbf{3 8 . 5 3 5 3}$ & 2.71274 & N.Cel et HCel
\end{tabular}

(N.Cl: native cellulose, HCel: hemicellulose dehydrate, C: solide carbone)

The XRD results show that RLK had of relative crystallinity $24.43 \%$ similar to results obtained by Hornung et al. [34]

\subsection{Surface functional groups.}

The infrared spectra of raw loquat kernels are illustrated in figure 3. The assignment of vibration bands was made based on previous work carried out on the compounds of the same family [35] (Table S1).

The $v(\mathrm{O}-\mathrm{H})$ stretching vibration that appears on the IR spectrum of RLK as a wide and intense massif centered around $3275 \mathrm{~cm}^{-1}$ is attributed to the alcoholic hydroxyl groups in phenolic and aliphatic structures [35,36] and/or glucopyranose rings commonly found in starch molecules [37]. Absorption bands observed at 1365, 1335, and $1416 \mathrm{~cm}^{-1}$ and the shoulder at $1305 \mathrm{~cm}^{-1}$ are related to the vibration of $\delta(\mathrm{O}-\mathrm{H})$ in-plane deformation of phenolic hydroxyl groups [36]. 


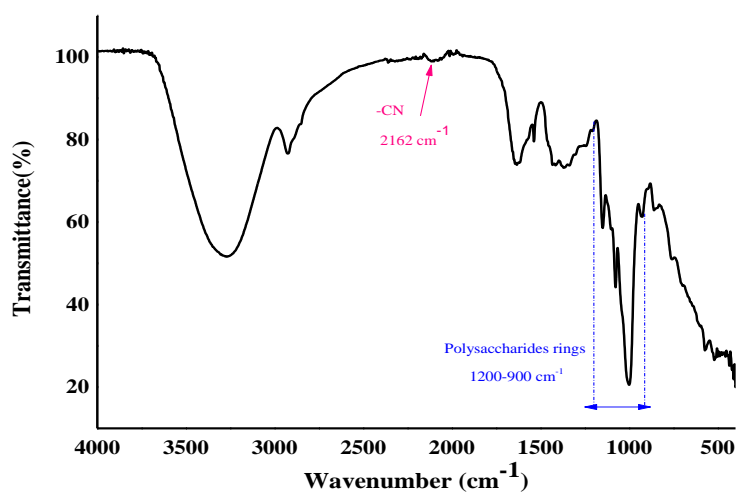

Figure 3. The infrared spectrum of raw loquat kernels.

The band located at $2929 \mathrm{~cm}^{-1}$ corresponds to the $v(\mathrm{C}-\mathrm{H})$ asymmetric stretching vibration of aromatic methoxyl groups $\left(-\mathrm{OCH}_{3}\right)$ and of methylene groups $\left(-\mathrm{CH}_{2}\right)$ of side chains $[36,35]$. Absorption bands presented in the form of the shoulder around 2884 and $2846 \mathrm{~cm}^{-1}$ are attributed respectively to stretching vibrations of symmetrical groups $\mathrm{CH}_{3}$ and $\mathrm{CH}_{2}\left(v^{\mathrm{s}} \mathrm{CH}_{3}\right.$ et $v^{\mathrm{s}} \mathrm{CH}_{2}$ ). The asymmetric and symmetric vibrations of the $\mathrm{CH}_{3}$ in-plane deformation group are respectively located at 1433 and $1365 \mathrm{~cm}^{-1}$. The band recorded at $1433 \mathrm{~cm}^{-1}$ can also be attributed to the shearing vibration of $\mathrm{CH}_{2}$. The $\gamma(\mathrm{C}-\mathrm{H})$ out-of-plane vibration in benzene gives rise to bands located at 929,854 , and $755 \mathrm{~cm}^{-1}$ [36].

An absorption band at $2146 \mathrm{~cm}^{-1}$ may be due to the stretching of the $-\mathrm{CN}$ group referring to the proteins existing in the composition of RLK [38]. The absorption band located at $1636 \mathrm{~cm}^{-1}$ is related to the $v(\mathrm{C}=\mathrm{O})$ stretching vibration of carbonyl groups [36]. This band may refer to acetyl and uronic ester groups of hemicelluloses or the ester linkage of carboxylic groups of the ferulic and $p$-coumaric acids of lignin and/or hemicelluloses [39] esters of pectins and galacturonic acid [39] could be responsible for this intense absorbance band. The two bands located in 1636 and $1538 \mathrm{~cm}^{-1}$, as well as the two shoulders located in 1576 and $1455 \mathrm{~cm}^{-1}$, are assigned to the skeletal vibrations of $v(C=C)$ in aromatic rings [36]. The stretching vibration for $v(C=C)$ in the aliphatic chain would be superimposed to the band centered at $1636 \mathrm{~cm}^{-1}$. The 1200-900 $\mathrm{cm}^{-1}$ region includes absorption peaks, the stretching of the $\mathrm{C}-\mathrm{O}, \mathrm{C}-\mathrm{C}$, and $\mathrm{C}-\mathrm{O}-\mathrm{H}$ bonds as well as the folding of the $\mathrm{C}-\mathrm{O}-\mathrm{H}$ bond [40] originating from the ring vibrations of the polysaccharide molecules [40]. Below $900 \mathrm{~cm}^{-1}$, other characteristic bands are found, including the absorption peak at $898 \mathrm{~cm}^{-1}$ of the $\mathrm{C}-\mathrm{O}-\mathrm{C}$ group at $\alpha-1,4$ and $\alpha-1,6$ glycosidic bonds [40].

\subsection{Surface morphology.}

Scanning electron micrographs for cross-sections of raw loquat kernels (RLK) are given in figure 4. The examination of the initial structure of the RLK, Fig.4.a, shows a bloated rough surface composed of blisters.

In right figure 4 , the dark parts correspond to the porosity and the light parts to the matter. Thus the Fig.4.b highlights a small proportion of the porosity compared to the matter, which would be in favor of an appreciable density. Furthermore, the matter is organized in a few agglomerates of blisters of various size and geometry on the surface. 

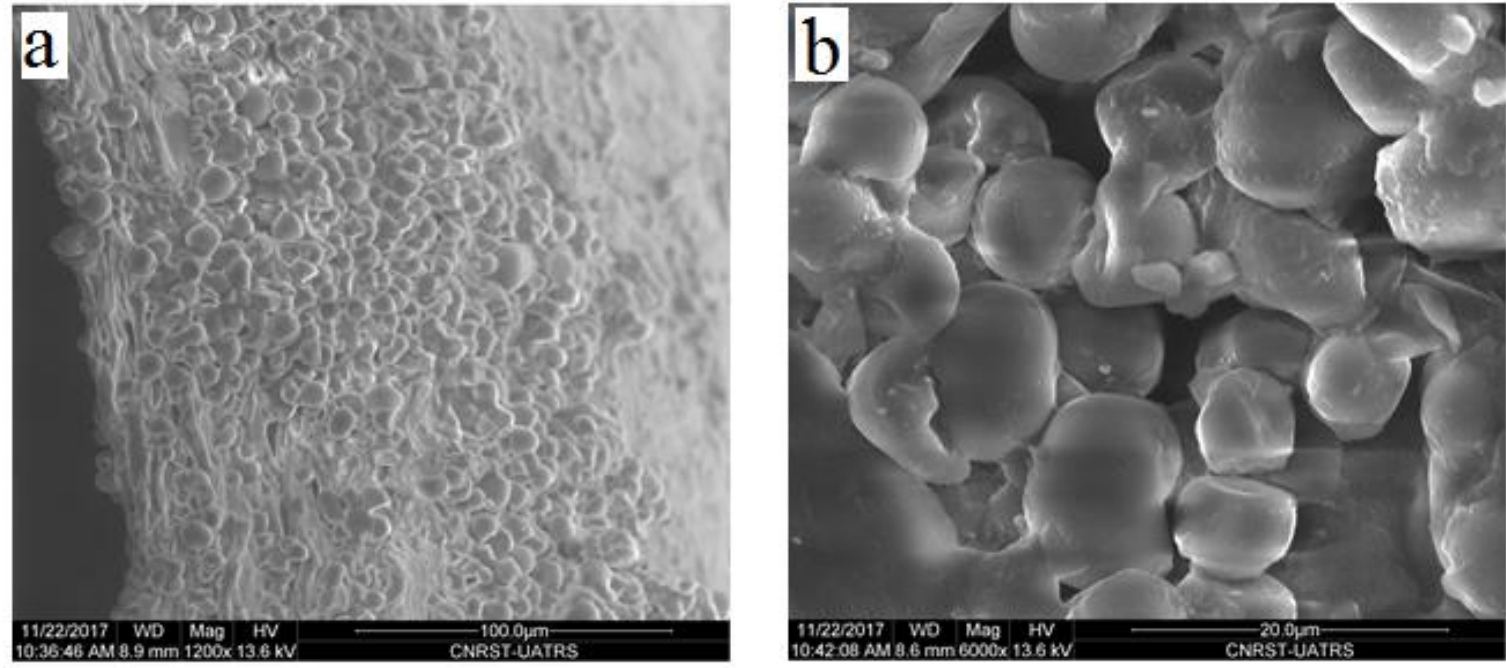

Figure 4. SEM images of a cross-section of loquat kernels.

\subsection{Thermogravimetric analysis.}

Figure 5 shows the TG/DTG curves that are mass loss of RLK as a function of temperature.

The TG curve highlights two zones of thermal decomposition, the first one with a loss of $17 \%$ and the second with a loss of $55 \%$. The first range, from room temperature to about 130 ${ }^{\circ} \mathrm{C}$, with a maximum peak around $90{ }^{\circ} \mathrm{C}$ on the derivative curve, is relative to dehydration. This latter would be linked to the departure of the so-called free water of the material retained in vessels and fiber lumens [41]. During this step, other volatile compounds may also leave the material as specified by some work [42].

The second zone, from 130 to $410{ }^{\circ} \mathrm{C}$, corresponds to the main pyrolysis. The loss of mass $55 \%$ and represents the volatile, condensable, and non-condensable matters emitted by the decomposition of the vegetable matter. At the end of the thermal treatment, the yield of solid residue, in this case, loquat kernels char, is $25 \%$ at $500{ }^{\circ} \mathrm{C}$.

The changes in the slope of TG curve in the temperature range between 130 and 410 ${ }^{\circ} \mathrm{C}$ indicate the decomposition of the different constituents of loquat kernels, which are hemicelluloses, cellulose, and lignin. The plot of the mass loss and that of mass loss derivative leads us to distinguish three groups of constituents and the intervals of their decomposition. Thus, between 130 and $230{ }^{\circ} \mathrm{C}$, the mass loss is of $5 \%$, on the derivative curve DTG, there corresponds a shoulder to $220{ }^{\circ} \mathrm{C}$, between 230 and $320{ }^{\circ} \mathrm{C}$ the loss is of $35 \%$, on the DTG curve, there corresponds a thin and strong peak at $300{ }^{\circ} \mathrm{C}$, and from 320 to $410{ }^{\circ} \mathrm{C}$ the loss is of $12 \%$. The literature on the thermal decomposition of vegetable matters [43-45] and that of loquat kernels [6] makes possible to attribute the first mass loss to the release of so-called, bounded, hygroscopic, or constitution water retained by cell walls and considered as adsorbed on hydroxyl functions of polysaccharides chains and lignin mainly by van der Waals and on the other hand, to the irreversible destruction of hemicelluloses and cellulose (holocellulose) [46]. It was also considered by certain authors (6) that between 180 and $280^{\circ} \mathrm{C}$, pyrolysis is in the torrefaction zone, where the solid residue has lost its ability to retain moisture. The second and the last mass loss are related to cellulose is the lignin thermal decomposition [46]. This latter decomposes at low temperatures, and its degradation continues as long as the thermal treatment is maintained [47, 48]. 
Figure 6 and 7 shows the DTA and DSC curves of raw loquat kernels. The DTA plot of RLK is given in Fig. 6. The DTA, as well as the DSC curve (Figures 6, 7b), shows, after the dehydration step, that the decomposition of loquat kernels is associated with exothermic heat flows.

Moreover, RLK presents a high temperature of thermal transition (figure 7c); this could be attributed to the higher protein content exhibited in the proximate composition analysis (Table 1) and also to a significant amount of starch (20\%) [12].

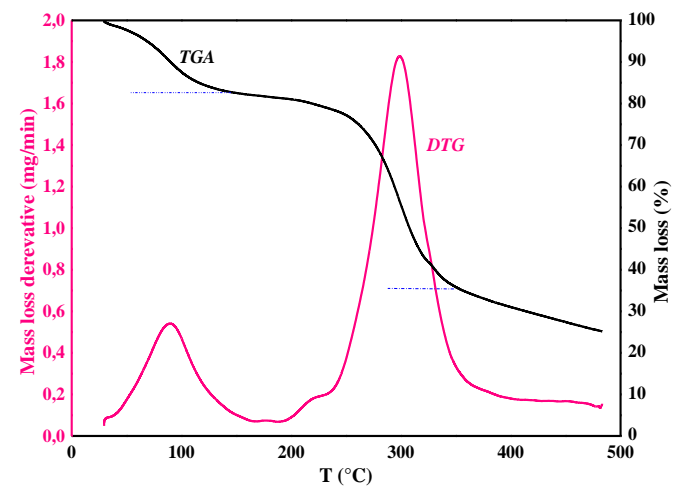

Figure 5. TG and DTG plots of loquat kernels.

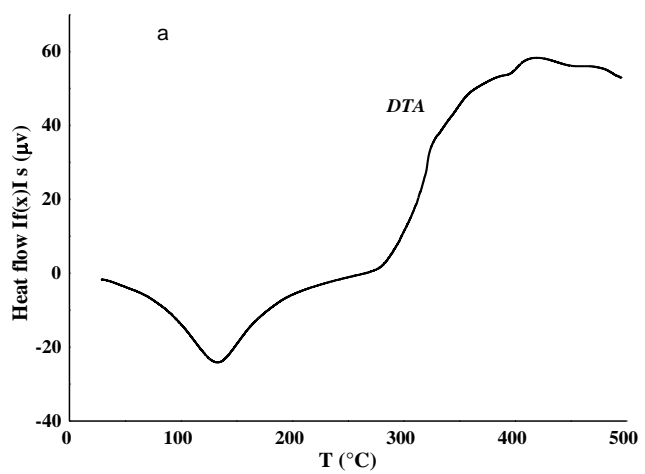

Figure 6. DTA plot of RLK.

Proteins have a physical barrier role since they form a matrix around the starch granules lowering their water absorption and delaying the transition and/or gelatinization process [12].
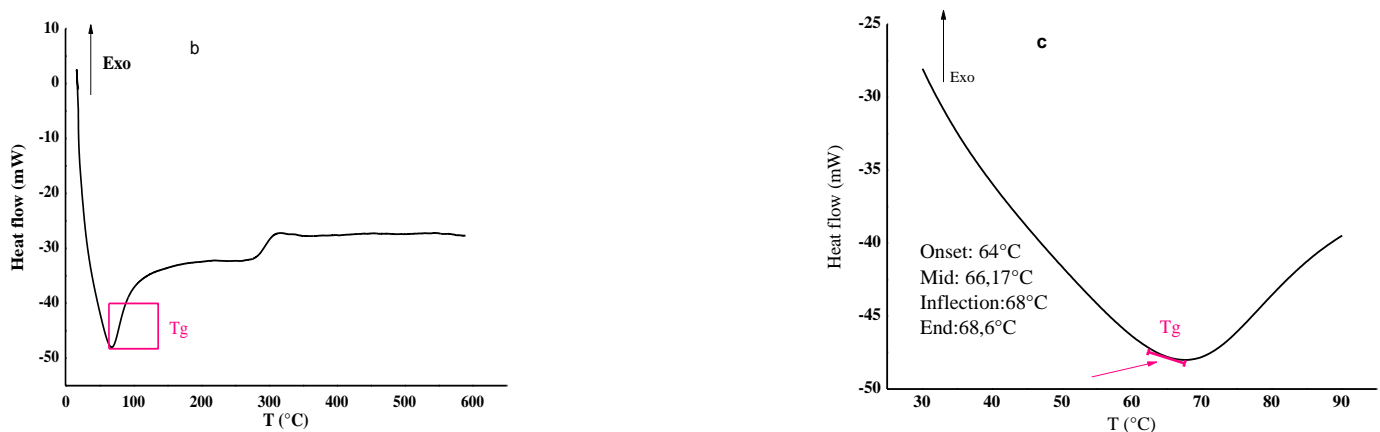

Figure 7. DSC curve of RLK (b), onset, mid-, and endpoints of the glass transition temperature (c). 


\subsection{Kinetic parameter estimation.}

In order to calculate and understand the nature of the decomposition, kinetic exploitation was made, with the assumption that carbonization is a global reaction made on dynamic chemical regime conditions, where physical limitations are minimized. The complete thermogram was divided into distinct sections according to their degradation steps. Curves indicating the solid-state mechanisms of loquat kernel degradation under inert atmosphere are shown in figure 8 . The values of activation energy $\mathrm{E}_{\mathrm{a}}$, pre-exponential factor $\mathrm{A}$ and correlation factors $\mathrm{R}^{2}$ for first and second degradation steps are listed in table 6 . Moreover, the parameters $\mathrm{A}$ and $\mathrm{E}_{\mathrm{a}}$ are moving in the same direction, and their values depend on the mode of degradation. The relationship between A and $\mathrm{E}_{\mathrm{a}}$, called "apparent compensation effect" is often mentioned in the literature. Figure 9 shows traces of the values of $\mathrm{Ln} \mathrm{A}$ as a function of $\mathrm{Ea}$. The effect of compensation is another way to further discrimination between degradation modes. Thus, for the first region (second weight loss step in TGA thermogram), it was observed from table 6 that the best correlation coefficients were obtained for F0, F1, F2, F3, R2, R3, P2, P3, D3, A2, and $\mathrm{A} 3$. In addition, energy values required for the degradation of loquat kernels in the first region are running from 24.34 to $117.06 \mathrm{~kJ} / \mathrm{mol}$. Regarding the second degradation step (third weight loss step), degradation mechanisms that give the best mathematical fit were F1, F2, F3, R3, and D3. Likewise, the results of the two regions show that the highest activation energies were found in the first thermal degradation region, where the main pyrolysis reaction took place, and the largest weight loss occurred.

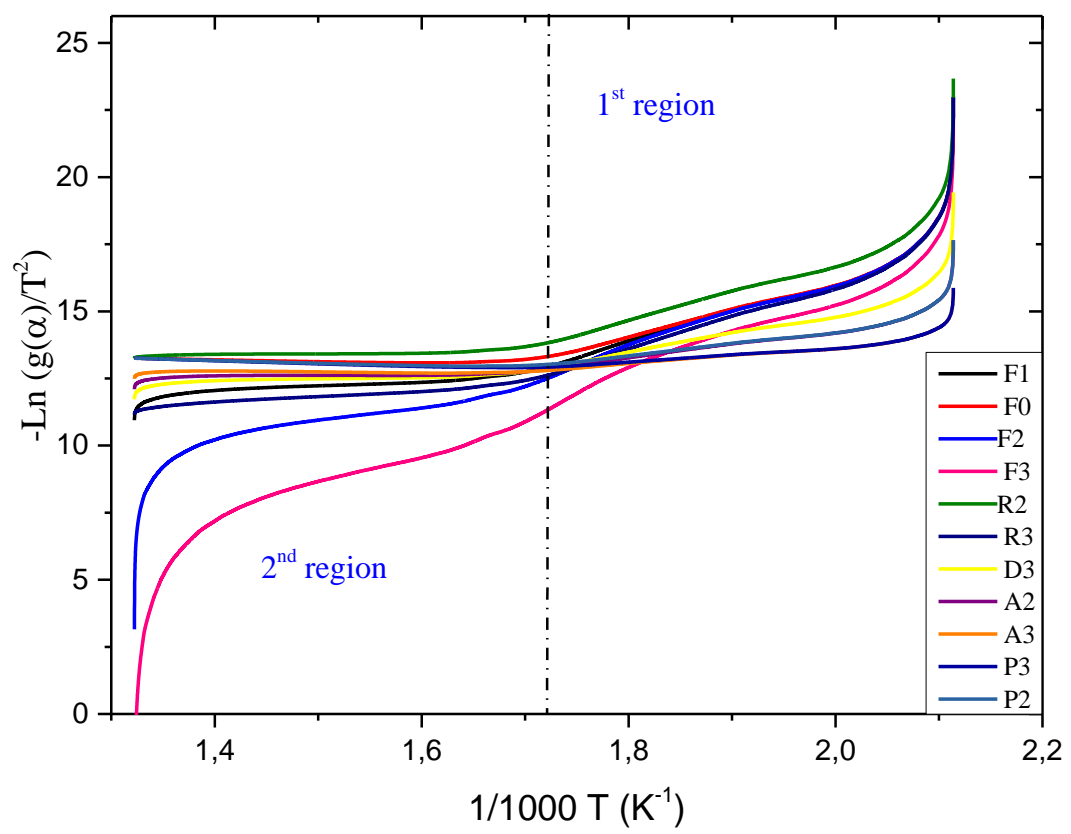

Figure 8. Curves indicating the solid-state mechanisms of pure and modified loquat kernels degradation under an inert atmosphere

Table 6. Thermal kinetic results for raw loquat kernels pyrolysis.

\begin{tabular}{l|c|c|c|c|c|c}
\multirow{2}{*}{ MD } & \multicolumn{3}{|c|}{$\boldsymbol{1}^{\text {st }}$ region } & \multicolumn{3}{c}{$\mathbf{2}^{\text {nd }}$ region } \\
\cline { 2 - 7 } & Ea & $\mathbf{R}^{\mathbf{2}}$ & $\mathbf{L n ~ A}$ & Ea & $\mathbf{R}^{\mathbf{2}}$ & Ln A \\
\hline F1 & 98.307 & 0.9807 & -1.968 & 16.567 & 0.947 & 12.907 \\
\hline F0 & 90.404 & 0.972 & -0.148 & -3.351 & 0.653 & - \\
\hline F2 & 107.164 & 0.983 & -4.013 & 63.821 & 0.883 & 4.272 \\
\hline F3 & 117.069 & 0.979 & -6.997 & 132.735 & 0.833 & -9.998
\end{tabular}




\begin{tabular}{l|c|c|c|c|c|c}
\multirow{2}{*}{ MD } & \multicolumn{3}{|c|}{$\boldsymbol{1}^{\text {st }}$ region } & \multicolumn{3}{c}{$2^{\text {nd }}$ region } \\
\cline { 2 - 7 } & Ea & $\mathbf{R}^{\mathbf{2}}$ & $\mathbf{L n} \mathbf{A}$ & $\mathbf{E a}$ & $\mathbf{R}^{\mathbf{2}}$ & $\mathbf{L n} \mathbf{A}$ \\
\hline $\mathrm{R} 2$ & 94.182 & 0.977 & -0.325 & 4.374 & 0.744 & 14.992 \\
\hline R3 & 104.879 & 0.982 & -3.613 & 19.720 & 0.975 & 12.122 \\
\hline P3 & 24.343 & 0.955 & 11.908 & -8.514 & 0.986 & - \\
\hline D3 & 62.574 & 0.978 & 4.914 & 7.679 & 0.877 & 14.005 \\
\hline P2 & 40.939 & 0.965 & 9.068 & -7.223 & 0.965 & - \\
\hline A2 & 44.756 & 0.976 & 8.235 & 3.147 & 0.654 & 14.064 \\
\hline A3 & 26.9 & 0.971 & 11.389 & -1.608 & 0.542 & -
\end{tabular}

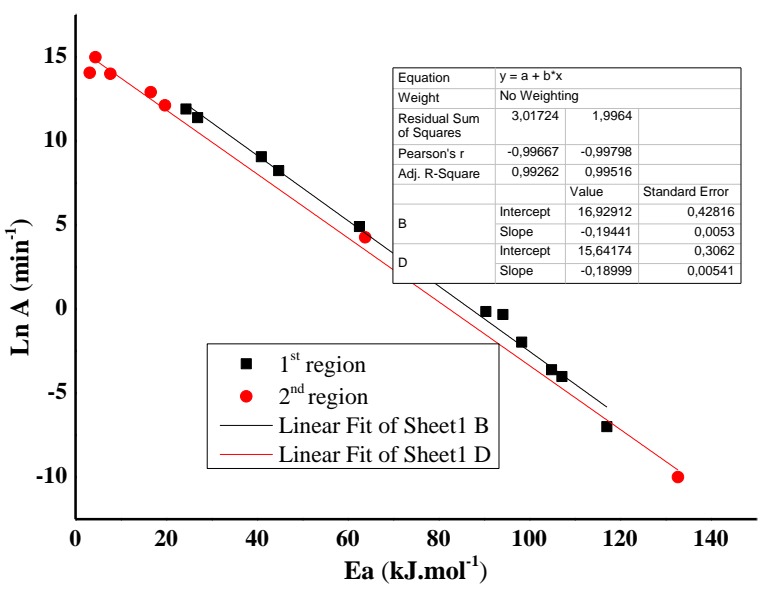

Figure 9. Compensation effect $\operatorname{Ln} A=f\left(E_{a}\right)$ for first and second regions of thermal degradation.

\section{Conclusions}

In this work, physico-chemical characteristics, polysaccharides composition, and thermal profile of raw loquat (Eriobotrya japonica Lindl.) kernels (RLK) have been investigated.

The proximate analysis shows that RLK has a relatively low moisture content, an absence of heavy metals, and an important amount of organic matter. Polysaccharides immunodetection indicates an important amount of un-esterified Homogalacturonan and Xyloglucanes with traces of Mannanes and Galactanes and the complete absence of Arabinanes and Xylanes among RLK polysaccharides.

$\mathrm{X}$-ray diffraction, the pattern indicates the presence of a small amount of crystalline cellulose. Surface functional groups and morphology (SEM) were also discussed. Loquat kernels were subjected to thermo-gravimetric analyzes under inert atmosphere from room temperature to $600{ }^{\circ} \mathrm{C}$ at a heating rate of $20{ }^{\circ} \mathrm{C} / \mathrm{min}$. TGA/DTG has enabled us to study the thermal profile of loquat kernels. Thus, the degradation of the major components occurs essentially between 130 and $410^{\circ} \mathrm{C}$. This degradation is associated with exothermic flow rates, a phenomenon detected by differential thermal analysis and differential scanning calorimetry. Kinetic parameters of the different stages involved in the thermal degradation of loquat kernels were investigated using the Coats-Redfern method. The best fit models for different degradation stages and their corresponding mechanisms were selected. Energy values required for the degradation of loquat kernels in the first region are running from 24.34 to $117.06 \mathrm{~kJ} / \mathrm{mol}$. The highest activation energies were found in the first thermal degradation region where the main pyrolysis reaction took place, and the largest weight loss occurred.

Calculation methods, sample nature, and experimental conditions lead to different kinetic parameters. Other modeling data and calculation methods for RLK will appear in our future publications. 


\section{Funding}

This research received no external funding.

\section{Acknowledgments}

This research has no acknowledgment.

\section{Conflicts of Interest}

The authors declare no conflict of interest.

\section{References}

1. Martinez-Calvo J.; Badenes, M.L.; Llacer, G.; Bleiholder, H.; Hack, H.; Meier, U. Phenological growth stages of loquat tree (Eriobotrya japonica (Thunb.) Lindl.). Ann. Appl. Biol. 1999, 134, 353-357, https://doi.org/10.1111/j.1744-7348.1999.tb05276.x.

2. Gisbert, A.D.; Romero, C.; Martinez-Calvo, J.; Leida, C.; Llacer, G.; Badenes, M.L. Genetic diversity evaluation of a loquat (Eriobotrya japonica (Thunb) Lindl) germplasm collection by SSRs and S-allele fragments. Euphytica 2009, 168, 121-134, https://doi.org/10.1007/s10681-009-9901-z.

3. Caballero, P.; Fernández, M.A. Loquat, production and market. In : First international symposium on loquat. Zaragoza : CIHEAM. Llácer, G.; Badenes, M.L. Options Méditerranéennes : Série A. Séminaires Méditerranéens, 2003, 58, 11-20, http://om.ciheam.org/om/pdf/a58/03600128.pdf.

4. Walali Loudyi D., Quelques espèces fruitières d'intérêt secondaire cultivées au Maroc In Llacer G.(ed)., Aksoy U.(ed).,Mars M.(ed).,Underutilized fruit corps in mediterranean region. Zaragoza: CIHEAM, 1995 (cahiers Options Méditerranéennes 13) 47-62, http://om.ciheam.org/om/pdf/c13/96605640.pdf.

5. Pareek, S.; Benkeblia, N.; Janick, J.; Cao S.; Elhadi, M.Y. Postharvest physiology and technology of loquat (Eriobotrya japonica Lindl.) fruit. J. Sci. Food Agric. 2014, https://doi.org/10.1002/jsfa.6560.

6. Sütcü, H.; Demiral, H. Production of granular activated carbons from loquat stones by chemical activation. J. Anal. Appl. Pyrol. 2009, 84, 47-52, https://doi.org/10.1016/j.jaap.2008.10.008.

7. Hamdaoui, O. Intensification of the sorption of Rhodamine B from aqueous phase by loquat seeds using ultrasound. Desalination 2011, 271, 279-286, https://doi.org/10.1016/j.desal.2010.12.043.

8. Handan UCUN, Equilibrium, thermodynamic and kinetics of reactive black 5 biosorption on loquat (Eriobotrya japonica) seed. Sci. Res. Essays. 2011, 6, 4113-4124, https://doi.org/10.5897/SRE11.674.

9. Taskin M.; Eedal, S. Utilization of waste loquat (Eriobotrya japonica Lindl.) kernel extract for a new cheap substrate for fungal fermentations. Rom. Biotech. Lett. 2011, 16, https://erepository.org/rbl/vol.16/iss.1/6.pdf.

10. Zhao, C.; Yan, H.; Liu, Y.; Huang, Y.; Zhang, R.; Chen C.; Liu, G. Bio-energy conversion performance, biodegradability, and kinetic analysis of different fruit residues during discontinuous anaerobic digestion. Waste Manage 2016, 52, 295-301., https://doi.org/10.1016/j.wasman.2016.03.028.

11. He, X.Y.; Wu, L.J.; Wang, W.X.; Xie, P.J.; Chen, Y.H.; Wang, F. Amygdalin - A pharmacological and toxicological review. J. Ethnopharmacol. 2020, 254, https://doi.org/10.1016/j.jep.2020.112717.

12. Turola Barbi, R.C.; Teixeira, G.L.; Hornung, P.S.; Ávila, S.; Hoffmann Ribani, R. Eriobotrya japonica seed as a new source of starch: Assessment of phenolic compounds, antioxidant activity, thermal, rheological and morphological properties. Food Hydrocoll. 2017, 77, 646-658, https://doi.org/10.1016/j.foodhyd.2017.11.006.

13. Brown, M.E. Introduction to Thermal Analysis: Techniques and Applications. 2nd Ed. New York Springer, 2001, https://doi.org/10.1007/0-306-48404-8.

14. Manyà, J.J.; Velo, E.; Puigjaner, L. Kinetics of Biomass Pyrolysis: A Reformulated Three-ParallelReactions Model Ind. Eng. Chem. Res. 2013, 42, 434-441, https://doi.org/10.1021/ie020218p.

15. AOAC Official methods of analysis of AOAC international. Virginia 16th ed., Volume 2. 1995.

16. AOAC Official Methods of Analyses. Washington, DC: Association of Official Analytical Chemist. 1997.

17. AOAC Official methods of analysis. 17th ed. Washington, DC: Associate of Official Analytical Chemist. 2000.

18. Egan, H.; Kirk, R.S.; Sawyer, R. Pearson's chemical analysis of foods. Ed. 8. Edinburgh, London, Melbourne and New York Churchill Livingstone. 1981, https://doi.org/10.1093/jaoac/65.4.1037.

19. Demirbas, A. Calculation of higher heating values of biomass fuels. Fuel 1997, 76, 431-434, https://doi.org/10.1016/S0016-2361(97)85520-2.

20. Plazanet, I.; Zerrouki, R.; Montplaisir, D.; Gady, C.; Boens, B.; Costa G. Effect of ionic liquids on dissolution and identification of wood polysaccharides. Ann Glycomics Lipidomics 2018, AGL-101 DOI: 10.29011/AGL-101/100001. 
21. Zhang, L.; Xie, W.; Zhao, X.; Liu, Y.; Gao, W. Study on the morphology, crystalline structure and thermal properties of yellow ginger starch acetates with different degrees of substitution. Thermochim. Acta. 2009, 495, 57-62, https://doi.org/10.1002/star.201000055.

22. Coats, A.W.; Redfern, J.P. Thermogravimetric analysis: A review. Analyst 1963, 88, 906-924, https://doi.org/10.1039/AN9638800906.

23. Coats, A.W.; Redfern, J.P. Kinetic parameters from the thermogravimetric data. Nature London 1964, 201, 68-69, https://doi.org/10.1038/201068a0.

24. Valensi, G. Essai de coordination des méthodes d'interprétation des réactions du type A solide $+\mathrm{B}$ gaz $\rightarrow$ C solide. J. Chim. Phys. 1950, 47, 489-505, https://doi.org/10.1051/jcp/1950470489.

25. Jander, W.; Anorg, Z. Kinetic Model for Solid-State Reactions. Z. Anorg. Allg. Chem. 1927, 163, 1-30.

26. Ginstling, A.; Brounshtein, Concerning the diffusion kinetics of reactions in spherical particles. J. Appl. ChcilL USSR, 1950, 23, 1327-1338.

27. Avrami, M. Kinetics of Phase Change. I General Theory J. Chem. Phys. 1939, 7, https://doi.org/10.1063/1.1750380.

28. Erofeev, B.V. Compt. Rend. Acad. Sci. URSS 1946, 52, 5111.

29. Karaosmanoglu, F.; Cift, B.D.; Ergudenler, A.I. Determination of reaction kinetics of straw and stalk of rapeseed using thermogravimetric analysis. Energy Sources 2001, 23, 767-774, https://doi.org/10.1080/009083101316862525.

30. Şensöz, S.; Can, M. Pyrolysis of Pine ( Pinus Brutia Ten.) Chips: 1. Effect of Pyrolysis Temperature and Heating Rate on the Product Yields. Energy Sources 2002, 24, 347-355, https://doi.org/10.1080/00908310252888727.

31. Kastanaki, E.; Vamvuka, D. A comparative reactivity and kinetic study on the combustion of coal-biomass char blends. Fuel 2006, 85, 1186-1193, https://doi.org/10.1016/j.fuel.2005.11.004.

32. Della Rocca, P.A.; Cerrella, E.G.; Bonelli, P.R.; Cukierman, A.L. Pyrolysis of hardwoods residues: on kinetics and chars characterization. Biomass and Bioenergy 1999, 16, 79-88, https://doi.org/10.1016/S09619534(98)00067-1.

33. Pietrzak, R. Sawdust pellets from coniferous species as adsorbents for $\mathrm{NO}_{2}$ removal. Bioresour. Technol. 2010, 101, 907-913, https://doi.org/10.1016/j.biortech.2009.09.017.

34. Hornung, P.S.; Ávila, S.; Lazzarotto, M.; da Silveira Lazzarotto, S.R.; de Andrade de Siqueira, G.L.; Schnitzler, E.; Ribani, R.H. Enhancement of the functional properties of Dioscoreaceas native starches: Mixture as a green modification process. Thermochimica Acta 2017, 649, 31-40, http://dx.doi.org/10.1016/j.tca.2017.01.006.

35. Hasegawa, P.N.; de Faria, A.F.; Mercadante, A.Z. ; Chagas, E.A. ; Pio, R.; Lajolo, F.M.; Cordenunsi, B.R.; Purgatto; E. Chemical composition of five loquat cultivars planted in Brazil. Ciência. Tecnol. Alim. 2010, 30, 552-559, http://dx.doi.org/10.1590/S0101-20612010000200040.

36. Silverstein R.M, Webster FX, Kiemle DJ, Bryce DL, Lafond V. Identification spectrométrique de composés organiques. $2^{\text {nd }}$ édition, De Boeck 2007.

37. Lomelí-Ramírez, M.G.; Barrios-Guzmán, A.J.; García-Enriquez, S.; de Jesús Rivera-Prado, J.; ManríquezGonzález, R. Chemical and Mechanical Evaluation of Bio-composites Based on Thermoplastic Starch and Wood Particles Prepared by Thermal Compression. BioResourses 2014, 9, 2960-2974, https://doi.org/10.15376/biores.9.2.2960-2974.

38. El-Hamshary, H.; El-Newehy, M.H.; Al-Deyab, S.S. Oxidation of phenol by hydrogen peroxide catalyzed by metal-containing poly (amidoxime) grafted starch. Molecules 2011, 16, 9900-9911, https://doi.org/10.3390/molecules16129900.

39. Belala, Z.; Jeguirim, M.; Belhachemi, M.; Addoun, F.; Trouve, G. Biosorption of basic dye from aqueous solutions by date stones and palm-trees waste: Kinetic, equilibrium and thermodynamic studies. Desalination 2011, 271, 80-87, https://doi.org/10.1016/j.desal.2010.12.009.

40. Warren, F.J.; Gidley, M.J.; Flanagan, B.M. Infrared spectroscopy as a tool to characterise starch ordered structure-a joint FTIR-ATR, NMR, XRD and DSC study. Carbohydrate Polymers 2016, 139, 35-42, https://doi.org/10.1016/j.carbpol.2015.11.066.

41. Kaufman, W.G. Le matériau bois - propriétés technologie. Mise en œuvre, Association pour la recherche sur le bois en Lorraine $\mathbf{1 9 8 3 .}$

42. Khiari, B.; Abed, I.; Jeguirim, M.; Zagrouba, F. Thermal conversion of date stones and palm stalks: experimental and kinetic study. In: Proceeding of the 11th international conference of environmental sciences and technology. Chania, Crete, Greece 2009, B-448-B455.

43. Carrier, M.; Loppinet-Serani, A.; Denux, D.; Lasnier, J.M.; Ham Pichavant, F.; Cansell, F.; Aymonier, C. Thermogravimetric analysis as a new method to determine the lignocellulosic composition of biomass. Biomass Bioenergy 2011, 35, 298-307, https://doi.org/10.1016/j.biombioe.2010.08.067.

44. Shah, M.A.; Khan, M.N.S; Kumar, V. Biomass residue characterization for their potential application as biofuels. J. Therm. Anal. Calorim. 2018, 134, 2137-2145, https://doi.org/10.1007/s10973-018-7560-9.

45. Nakanishi, M.; Ogi, T.; Endo, Y.; Otaka. M. Effect of carbonization temperature on composition of carbonized woody biomass. J Therm Anal Calorim. 2017, 130, 1117-23, https://doi.org/10.1007/s10973017-6484-0. 
46. Cruz, G.; Santiago, P.A.; Braz, C.E.M.; Jr Seleghim, P.; Crnkovi, P.M. Investigation into the physicalchemical properties of chemically pretreated sugarcane bagasse. J. Therm. Anal. Calorim 2018, 132, 103953, https://doi.org/10.1007/s10973-018-7041-1.

47. Kifani-Sahban, F.; Kifani, A.; Belkbir, L.; Zoulalian, A.; Arauso, J.; Cordero, T. A physical approach in the understanding of the phenomena accompanying the thermal treatment of lignin. Thermochim. Acta. 1997, 298, 199-204, https://doi.org/10.1016/S0040-6031(97)00115-9.

48. Antal, M.J. Jr. Chapter 4 Biomass pyrolysis: a review of the literature Part 2: lignocellulose pyrolysis. In: Advances in solar energy. Duffie, J.A.; Boer, K.W. editors. New York, Plenum Volume 3, 1984; pp 175255. 


\section{Supplementary files}

Table S1. Assignement of fundamental vibrations of RLK.

\begin{tabular}{|c|c|c|}
\hline $\begin{array}{c}\text { Vibrational } \\
\text { frequencies }\left(\mathrm{cm}^{-1}\right)\end{array}$ & \multicolumn{2}{|c|}{ Assignement } \\
\hline $3275(\mathrm{~S})$ & \multicolumn{2}{|c|}{$v(\mathrm{O}-\mathrm{H})$ ass } \\
\hline $2929(w)$ & $\mathrm{U}^{\text {as }} \mathrm{CH} 3$ & \multirow{3}{*}{$\begin{array}{l}v(\mathrm{C}-\mathrm{H}) \text { in methyl and } \\
\text { methylene groups }\end{array}$} \\
\hline $2884(\mathrm{sh})$ & $\mathrm{v}^{\text {as }} \mathrm{CH} 2$ & \\
\hline $2846(\mathrm{sh})$ & $v^{\mathrm{s}} \mathrm{CH} 3$ et $/ \mathrm{Ou} v^{\mathrm{s}} \mathrm{CH} 2$ & \\
\hline $1636(\mathrm{M})$ & \multicolumn{2}{|c|}{$v(\mathrm{C}=\mathrm{O})$} \\
\hline $1636(\mathrm{M})$ & \multicolumn{2}{|c|}{ v $(\mathrm{C}=\mathrm{C})$ aliphatic } \\
\hline $1636 \mathrm{M}$ & \multirow{4}{*}{\multicolumn{2}{|c|}{$v(\mathrm{C}=\mathrm{C})$ aromatic }} \\
\hline $1576(\mathrm{sh})$ & & \\
\hline $1538(\mathrm{M})$ & & \\
\hline $1455(\mathrm{sh})$ & & \\
\hline $1433(\mathrm{M})$ & \multicolumn{2}{|c|}{$\delta^{\mathrm{as}} \mathrm{CH}_{3}$ et $\delta \mathrm{CH} 2$} \\
\hline $1416(\mathrm{~m})$ & \multicolumn{2}{|c|}{$\delta(\mathrm{O}-\mathrm{H})$ phenolic hydroxyl groups } \\
\hline $1365(w)$ & \multicolumn{2}{|c|}{$\delta^{\mathrm{s}} \mathrm{CH} 3, \delta_{\mathrm{OH}}$} \\
\hline $1335(\mathrm{w})$ & \multirow{2}{*}{\multicolumn{2}{|c|}{$\delta(\mathrm{O}-\mathrm{H})$}} \\
\hline $1305(\mathrm{w})$ & & \\
\hline $1237(\mathrm{~m})$ & \multirow{4}{*}{\multicolumn{2}{|c|}{$\mathrm{v}^{\mathrm{a}}(\mathrm{C}-\mathrm{O}-\mathrm{C})$ and/or vC-OH }} \\
\hline $1203(w)$ & & \\
\hline $1155(\mathrm{~S})$ & & \\
\hline $1102(\mathrm{sh})$ & & \\
\hline $1079(\mathrm{M})$ & \multicolumn{2}{|c|}{$v^{s} \mathrm{C}-\mathrm{O}-\mathrm{C}$ and/or $v \mathrm{C}-\mathrm{OH}$} \\
\hline 1004 (VS) & \multicolumn{2}{|c|}{ vC-O ether $\left(-\mathrm{CH}_{2}-\mathrm{O}-\mathrm{C}\right)$} \\
\hline $929(\mathrm{M})$ & \multirow{3}{*}{\multicolumn{2}{|c|}{$\gamma(\mathrm{C}-\mathrm{H})$}} \\
\hline $854(\mathrm{M})$ & & \\
\hline $756(\mathrm{~m})$ & & \\
\hline
\end{tabular}

Vibration intensities: sh: shoulder; M: Medium to strong; m: Medium; S: Strong; w: weak; VS: Very strong 